Acta vet. scand. 1961, 2, 157-177.

From the Department of Anatomy and Histology and the Department of Obstetrics and Gynecology, Royal Veterinary College, Stockholm, Sweden.

\title{
A MORPHOLOGICAL STUDY ON RETENTIO SECUNDINARUM IN CATTLE')
}

By

Nils Björkman and Per Sollén.

Retentio secundinarum (Ret. sec.) is a common complication of partus in cattle. The etiology seems to be rather complex, and several factors, single or in combination, have been considered responsible for the disease in question. Many authors $(5,6,7,12$, 15, 16) have stated placentitis to be the dominant or even exclusive cause of Ret. sec., though placentitis has also been regarded as a secondary phenomenon (10). In an investigation of experimentally induced Ret. sec. (11) no placentitis was reported.

Several other circumstances that have a disturbing influence on the delivery of the afterbirth have been reported, though their connection with the histological picture of the placentome has not been studied. Thus allergic conditions, metabolic disturbances, and poisoning have been mentioned as etiological factors (6) as well as deficiency of vitamin $A(8,14)$ and trace elements (17). Cases that may be interpreted as hereditary disposition for Ret. sec. have also been reported (5).

It is well known that abortion is as a rule followed by Ret. sec., but also an abnormally long time of gestation is likely to cause Ret. sec. (4). The observation (13) that Ret. sec. is more frequent when the offspring is male (70\%) than when it is female (30\%) might point to influence from sex hormones. A significant hormonal influence was demonstrated by McDonald et al. (11) who induced Ret. sec. by removing the corpus luteum in pregnant cows and then supplied the need of progesterone by injections, which were stopped at least 24 days ante partum.

1) This investigation has been supported by a grant from Jordbrukets Forskningsråd, Stockholm, Sweden. 
The concept of the direct cause of the retentio is somewhat vague in the literature. Incarceration of chorionic villi within the crypts has been stated as a cause $(6,12,13,15)$ but its significance has also been denied (10). Kennedy (9) could see no difference in the histological picture of the placentomes, whether the afterbirth was later delivered normally or was retained. $\mathrm{He}$ considered the etiology unsolved.

As it is essential to know the normal mechanism of the anchoring and delivery of the foetal membranes before an understanding of the retention can be obtained, we have previously studied the morphology of the placenta at normal delivery (3). It was shown that the separation mainly occurred at the contact surface between trophoblast and cryptal epithelium, and that after separation the cells were intact to a considerable extent. The manner in which the foetal membranes are anchored to the endometrium was discussed and earlier theories were reviewed.

To continue that investigation we have examined a number of cases of spontaneous Ret. sec. Among them we have studied placentomes from retained afterbirths at intervals from the time of partus.

\section{MATERIAL}

The investigation was undertaken on cows of the SRB breed (Swedish Red and White Cattle) in the veterinary district of the Royal Veterinary College, Stockholm. Two different groups were studied. The first group comprised spontaneous cases of retained afterbirth reported by the owners of the animals to the Ambulatory Clinic. The second group comprised cows with spontaneous Ret. sec., which had calved at the Stationary Clinic and which were subject to repeated sampling.

The cows from the first group were studied and treated in the byres. A clinical examination of the cows was undertaken. It was based on the anamnesis and inspection of general condition, appetite, temperature, pulse frequency, and heart action. According to this examination the animals were arbitrarily classified as "healthy" or "sick". Cows with a bad appetite were always found to have a heightened temperature though not necessarily very high. In cows with a good appetite and a good condition the temperature and pulse frequency was ranging within rather wide limits. In the classification the appetite was considered the most important factor. Placentomes were collected 
from each cow. The afterbirth was removed, if this was easily managed, otherwise not.

Afterbirths that could be removed without damage on the cotyledons and with the chorionic villi intact were regarded as "removable". If on operation the cotyledons were damaged, they were regarded as "not removable".

According to the above mentioned classifications the results obtained were set out in the following table:

\begin{tabular}{lrcc}
\hline \multirow{2}{*}{ Cows } & \multicolumn{3}{c}{ Cotyledons } \\
& Removable & Not removable & \\
\hline "Healthy" & 24 & 37 & 61 \\
"Sick" & 5 & 12 & 17 \\
Total & 29 & 49 & 78 \\
\hline
\end{tabular}

The data of the offsprings, when available, were recorded as follows:

\begin{tabular}{lllcc}
\hline & $\sigma^{7}$ & क & twins & abortion \\
\hline alive & $23(66 \%)$ & $12(34 \%)$ & 6 & 17 \\
dead & 1 & 2 & 5 & \\
\hline
\end{tabular}

The sex ratio $\left(\sigma^{x}: q=66: 34\right)$ was recorded for single born, living calves only, as particular circumstances might have preponderated over the sex influence in the rest of the material. We have defined abortion as termination of pregnancy within 274 days, as such cases have shown an increased frequency of Ret. sec. (4).

The second group comprised 15 cows. Four cows had Ret. sec. without other complications and three had twins. Two cows, which had suffered earlier from Ret. sec. were acquired for the investigation as they were suspected to get Ret. sec. again, which they actually did. In adidtion 6 cows were examined, which had retained their placentae because of traumata. Two of them had been subject to caesarian section, and 4 cows had been experimentally injected in the amniotic sac with serum from leucaemic cows. The latter cows aborted after 8 months of gestation and retained their foetal membranes. (A fifth cow in this series, who also aborted, delivered her afterbirth spontaneously). Most afterbirths in this group were removable. 


\section{METHODS}

From the first group placental tissue was in most cases sampled 2 days post partum. In a few cases the material was gained immediately or 1 or 3 days post partum. The placentomes were loosened from their stalks and cut into blocks, which were immediately fixed. The fixatives used were formaldehyde solution (10\%), Bouin's, Serra's, and Helly's fluids. After fixation in Helly's fluid the tissue blocks were postchromated for 4 days in a saturated solution of potassium-dichromate at $37^{\circ} \mathrm{C}$. After dehydration, embedding in paraffin, and sectioning, the staining was performed with hemalum and eosine, Azan, and periodic acid Schiff (PAS). Frozen sections from formaldehyde fixed blocks were stained with Sudan III or Sudan Black B.

Placentomes from the second group were taken immediately after partus and then at intervals of 1, 2, 4, and 8 hours and after 1,2 , and 3 days. To prevent the uteri from infections they were treated with antibiotics. The tissue was treated as in the first group. From the second group samples from the placentomes taken at partus were also fixed in isotonic buffered osmiumtetroxide, prepared for electron microscopy and examined in a Siemens Elmiskop I.

\section{OBSERVATIONS}

The description will be divided into three parts: 1) The "healthy" cases, 2) the "sick" cases of the first group, and 3) the cases studied at the stationary clinic.

Placentomes from "healthy" cows.

In placentomes from cows which deliver the afterbirth normally the maternal as well as the foetal epithelium is basically intact, and the two layers are attached to each other at the cellular level by means of a stainable suture of interdigitating microvilli $(2,3)$ (cf. Figs. 8, 12). Placentomes which were taken immediately after partus of cows that afterwards got Ret. sec. and which were easily removable, showed a picture reminiscent of the normal ones. Thus a normal trophoblast with ordinary trophoblastic cells and giant cells covered the core of mesenchyme in the chorionic villi. Along the large primary villi and the allanto-chorionic membrane surrounding the placentome the trophoblast had a pronounced phagocytotic activity. In the small 


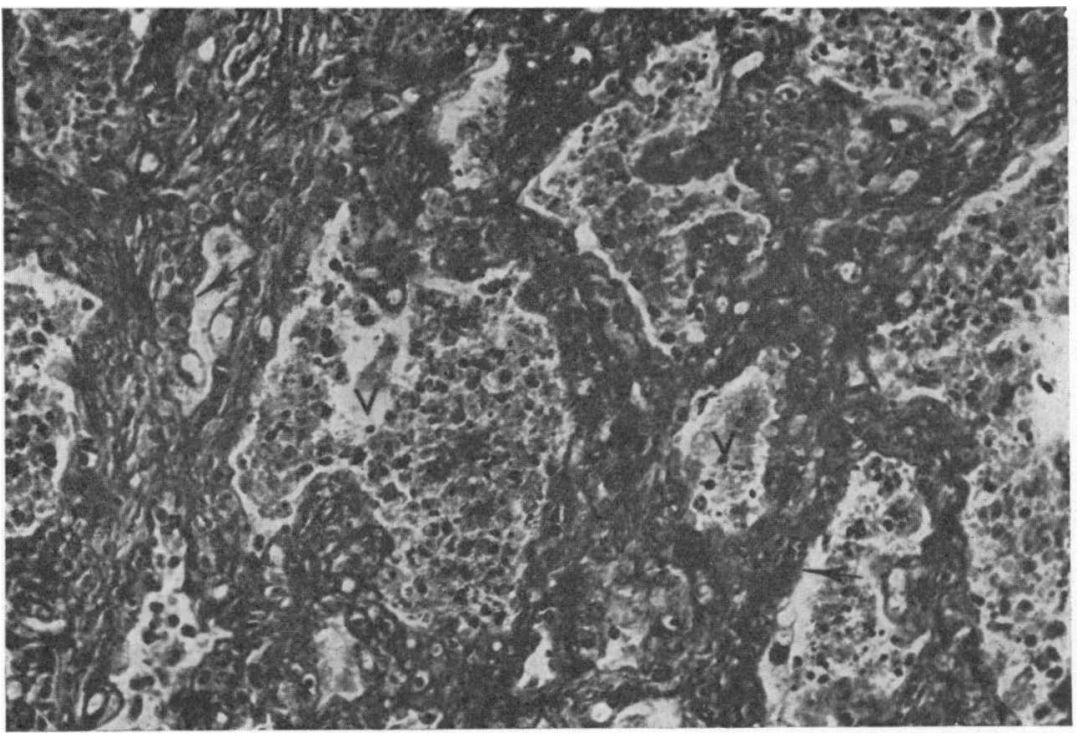

F i g. 1. Placentome with macerated chorionic villi (V) and partly denuded cryptal walls (arrows). The sample was taken 2 days post partum. Easily removable. Azan. Photomicrograph $220 \times$.

villi of the higher order the trophoblast adhered to the cryptal epithelium. This was not the case of the trophoblast of the large primary villi, however. The differences from normal placentae were found in the cryptal epithelium. Thus in part of the placentome it was atrophied and in some cases cells were desquamated leaving the stroma denuded. However, such findings could be made in normal placentomes, too, although to a less extent. On the other hand, the mentioned alterations were not necessarily found in all retained afterbirths.

Most samples were taken $2-3$ days post partum, and in them widespread alterations were always seen. The small chorionic villi of higher orders were most altered. After one day part of them were completely macerated (Fig. 1), but there were also intact villi and besides there were transitional stages of autolysis. The degeneration began with vacuolization of the cytoplasm and concentration of the chromatine. The maceration was found to begin in the trophoblast, and there the ordinary trophoblastic cells were affected first, whereas the giant cells were more resistant. The detritus consisted of dissolved cytoplasm and fragmentated nuclei. 


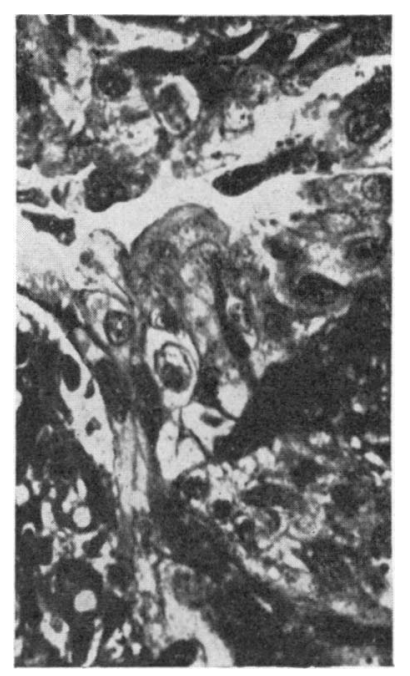

F i g. 2. Hypertrophied cryptal epithelium. 3 days post partum. Azan. $400 \times$.

Sudanophilic lipid droplets occur in great amounts in the cryptal epithelium but are nearly absent in the trophoblast of premature placentomes (1). Similar observations were made on placentomes at normal delivery (3). In retained placentae a few small lipid droplets were found in the trophoblast at partus. During the process of maceration additional lipids became unmasked, and thus the detritus contained a fairly great amount of lipid droplets.

The mesenchymal core survived for a considerably longer time. There were also necroses in some villi or in part of them. After 2 days the areas of macerated villi were larger. The larger primary villi were as a rule intact but part of the trophoblast was more or less disturbed. After 3 days the regressive alterations had proceeded further, but even at that time parts of some placentomes were found where chorionic villi were quite intact to their very tips. There were also villi that were shrunken but seemed to have been alive even at the time of sampling.

The cryptal epithelium was not macerated in the same way as the villi. The cryptal cells were normal or atrophied, but to a large extent they had fallen off leaving the stroma denuded. In some crypts, however, the epithelium had proliferated or rather hypertrophied (Fig. 2).

The foetal-maternal relationship presented varying pictures 


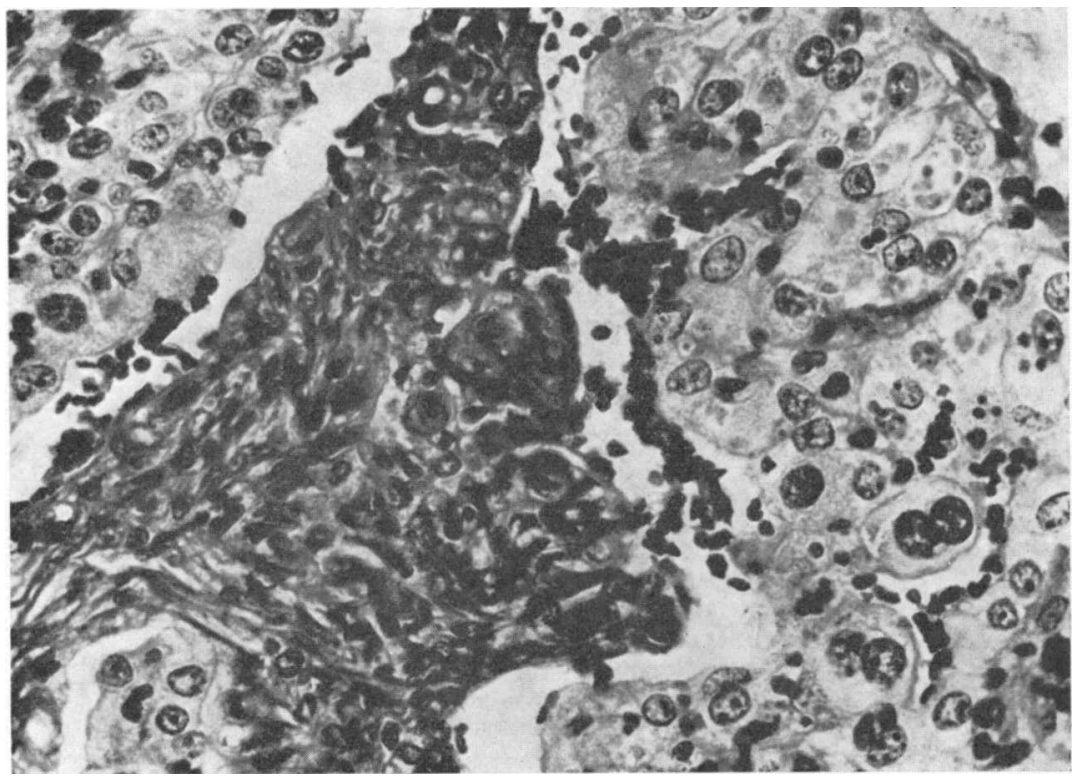

F i g. 3. Red cells between denuded cryptal wall (middle) and trophoblast (right and left). Taken at partus. Azan. $440 \times$.

in different placentomes. In crypts where the villi were macerated the cryptal epithelium was as a rule cuboidal, squamous, or absent. In crypts where the villi were still intact the cryptal epithelium was as a rule cuboidal. Sometimes the brush borders were seen on the trophoblast as well as on the cryptal epithelium. If the trophoblast adhered to the cryptal epithelium, the suture of the interdigitating microvilli could be observed as a stained line. If the cryptal epithelium was hypertrophied, the chorionic villi, if present, were not macerated but were either intact or shrunken. In some parts the villi had left the crypts and the latter were collapsed.

In the periphery of the placentomes the cup-shaped endings of the septa were usually provided with a columnar epithelium, which was as a rule intact and had a distinct brush border as in normal placentomes.

The group described above was rather homogeneous in appearance. In placentomes from afterbirths that were considered not to be removable or were removable with difficulty the picture differed from that in placentomes from easily removable placentae. Wide variations in the structure and degree of alterations 


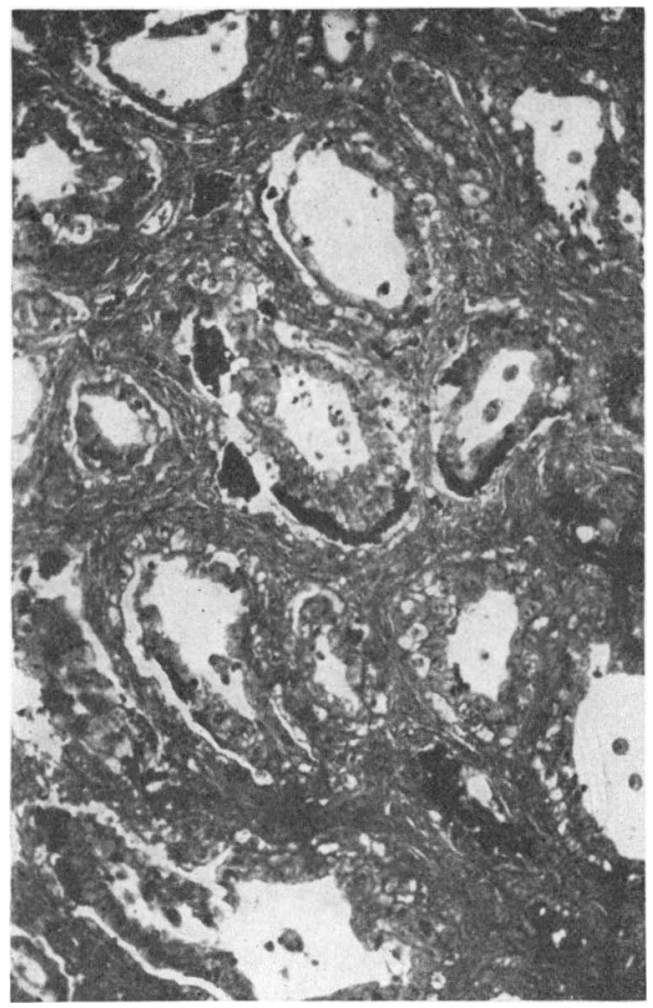

F i g. 4. Placentome with necroses (black spots) and villi with large mesenchymal cores. 2 days post partum. Firmly attached. Azan. $150 \times$.

were found, and different types of alterations were distinguished. In one and the same placentome areas of very different appearance were often seen: fresh placental tissue, necrotic villi, macerated villi. Placentae that were not very easy to remove but which were nevertheless possible to take out constituted an intermediate group where the maceration of the chorionic villi dominated. If they were more firmly attached, the sites of maceration were less pronounced or rather absent. Instead many villi were often more or less intact several days post partum. The trophoblast of these villi often had a content of lipid droplets that was higher than normal.

A characteristic feature of most firmly attached placentae was the presence of necrotic portions. Judging from the picture these necroses have been preceded by bleedings between the chorionic villi and cryptal walls (Fig. 3). Small groups of red 


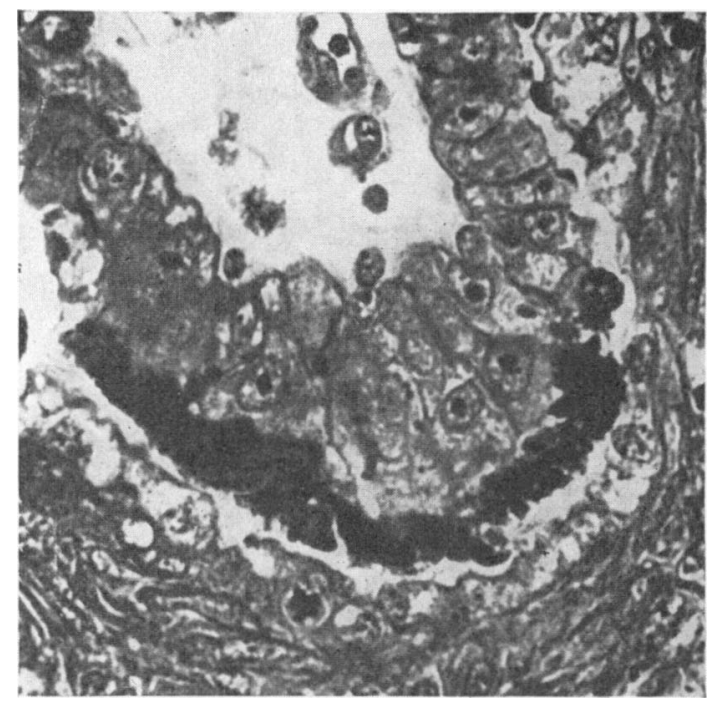

F i g. 5. Enlargement from Fig. 4 showing a necrosis covering a villus. $600 \times$.

cells were also present within the trophoblast. The necroses as a rule comprised part of the villi, especially their tips (Figs. 4 $\& 5$ ). Thus they formed an intervening barrier between the villus and the cryptal wall. Sometimes whole twigs of villi were necrotic (Fig. 6). Demarcated rounded necroses were also found in close relation to the denuded cryptal wall (Fig. 7). The necroses thus comprised trophoblast, cryptal epithelium, and erythrocytes with the trophoblast as the dominating constituent. These necroses were found in placentomes sampled immediately after partus. In such placentomes the changes during the first 2 or 3 days following partus were inconsiderable, and the fresh villi remained unaffected. Necrotic tips of villi were also observed in placentomes from abortion cases (one month too early). These findings indicate that the necroses arise before partus. The necroses, however, were of varying extension. They could be found as small spots in restricted areas or as large masses intervening between the villi and the cryptal epithelium. The latter was often atrophic or desquamated, and was as a rule more affected than the epithelium of the easily removable placentae. In part of the placentomes the foetal as well as the maternal placental tissue survived for several days after partus. The epithelia then resembled those of fresh, normal placentomes (Fig. 8). 


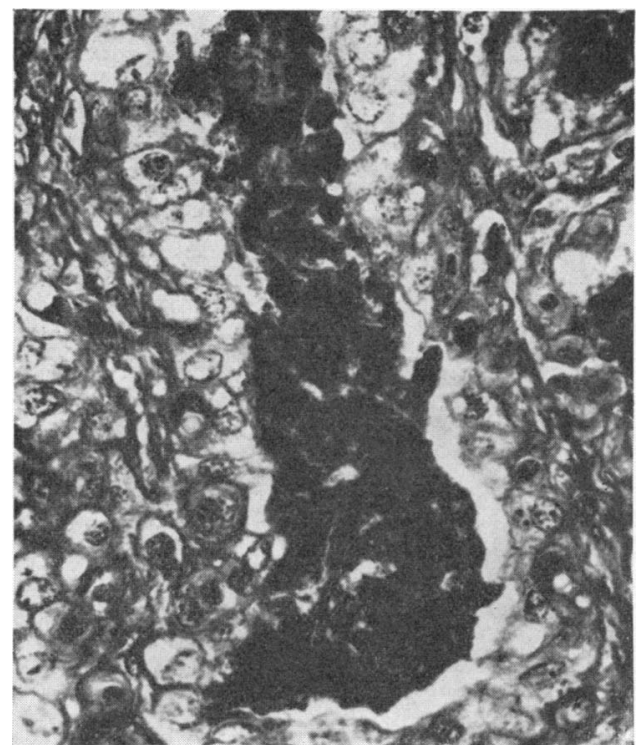

F i g. 6. Necrotic villus in a crypt with intact epithelium. 2 days post partum. Firmly attached. Azan. $440 \times$.

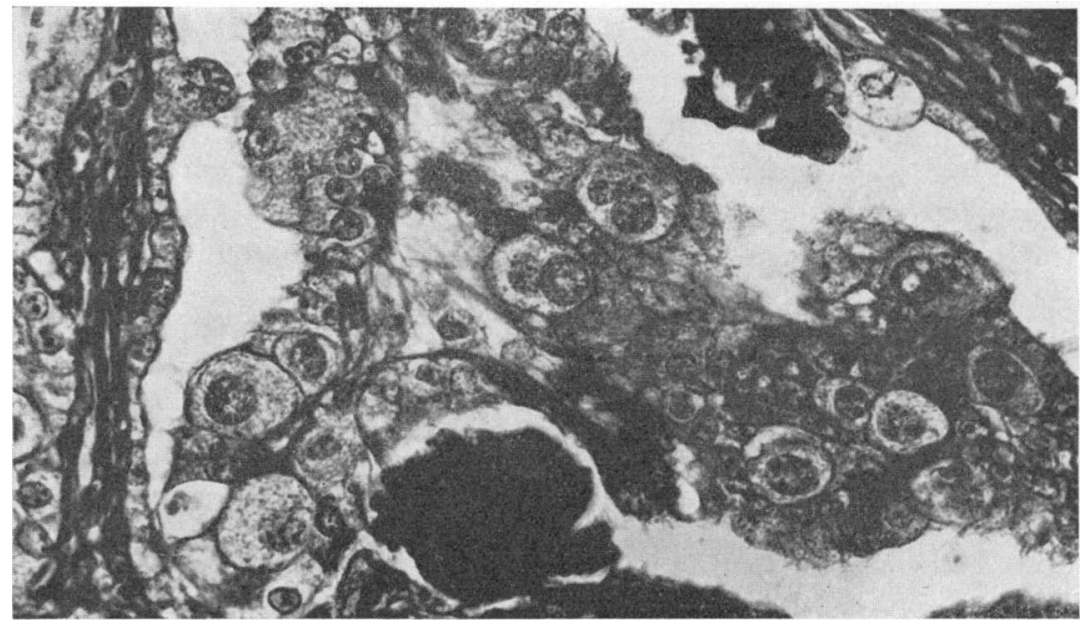

F i g. 7. Chorionic villus with intact trophoblast in a crypt where the lining epithelium is flattened (left) or absent (bottom). Two demarcated necroses are seen (top right and bottom middle). 2 days post partum. Firmly attached. Azan. $440 \times$. 


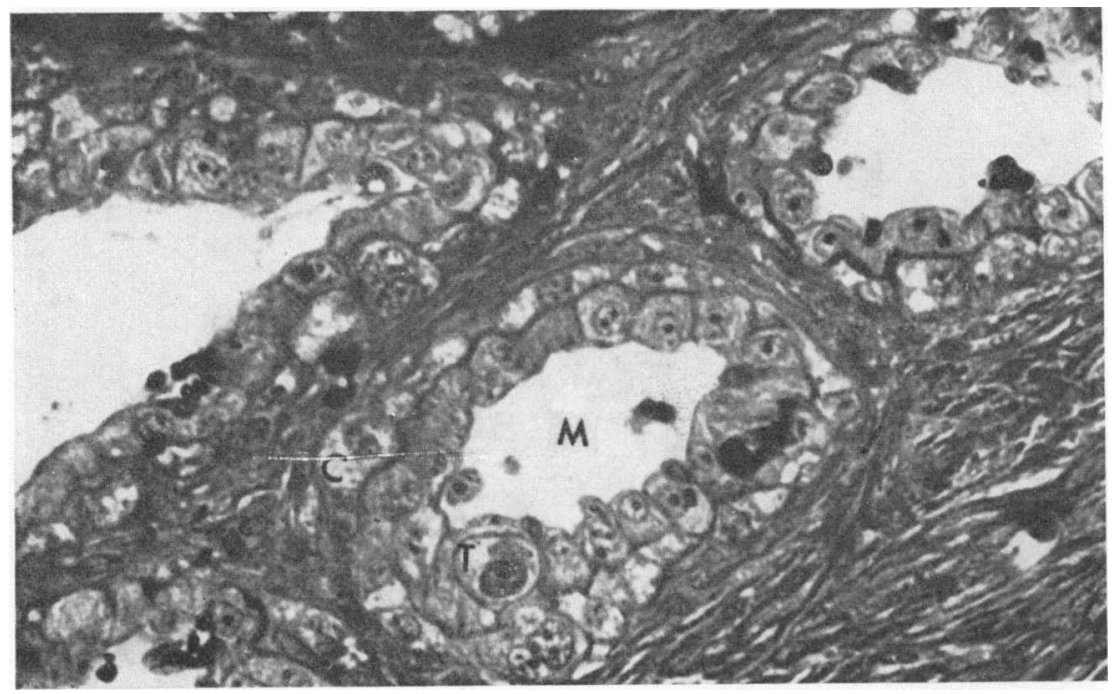

F i g. 8. Completely intact villi and crypts 2 days post partum. Firmly attached. $\mathrm{M}=$ mesenchyme, $\mathrm{T}=$ trophoblast, $\mathrm{C}=$ cryptal epithelium, Azan. $360 \times$.

One type of firmly fixed afterbirth was represented by placentomes that appeared completely fresh even several days post partum. In these placentomes the foetal component was dominating, the cryptal epithelium often being thin. The chorionic villi also had large mesenchymal cores (cf. Figs. $4 \& 8$ ). The suture of mutually interdigitating microvilli was less stainable than in normal placentomes or placentomes from easily removable afterbirths. This type of placentome was often found in abortion cases or twin births. It seems therefore as if these afterbirths were not yet ready for delivery.

A quite different type of afterbirths which are difficult to remove was represented by cases where most of the villi were macerated and the cotyledons would consequently be expected to be easily removable, but where the membranes were too fragile to resist manual treatment.

In one type of firmly attached afterbirths the placentae were hyperaemic. In such cases the hyperaemia was as a rule found on one side of the placental barrier (Fig. 9). Either the chorionic villi or the walls of the septa were hyperaemic but not often both. The hyperaemia was in general found locally in the placentomes and was sometimes associated with bleedings. The capillary net 


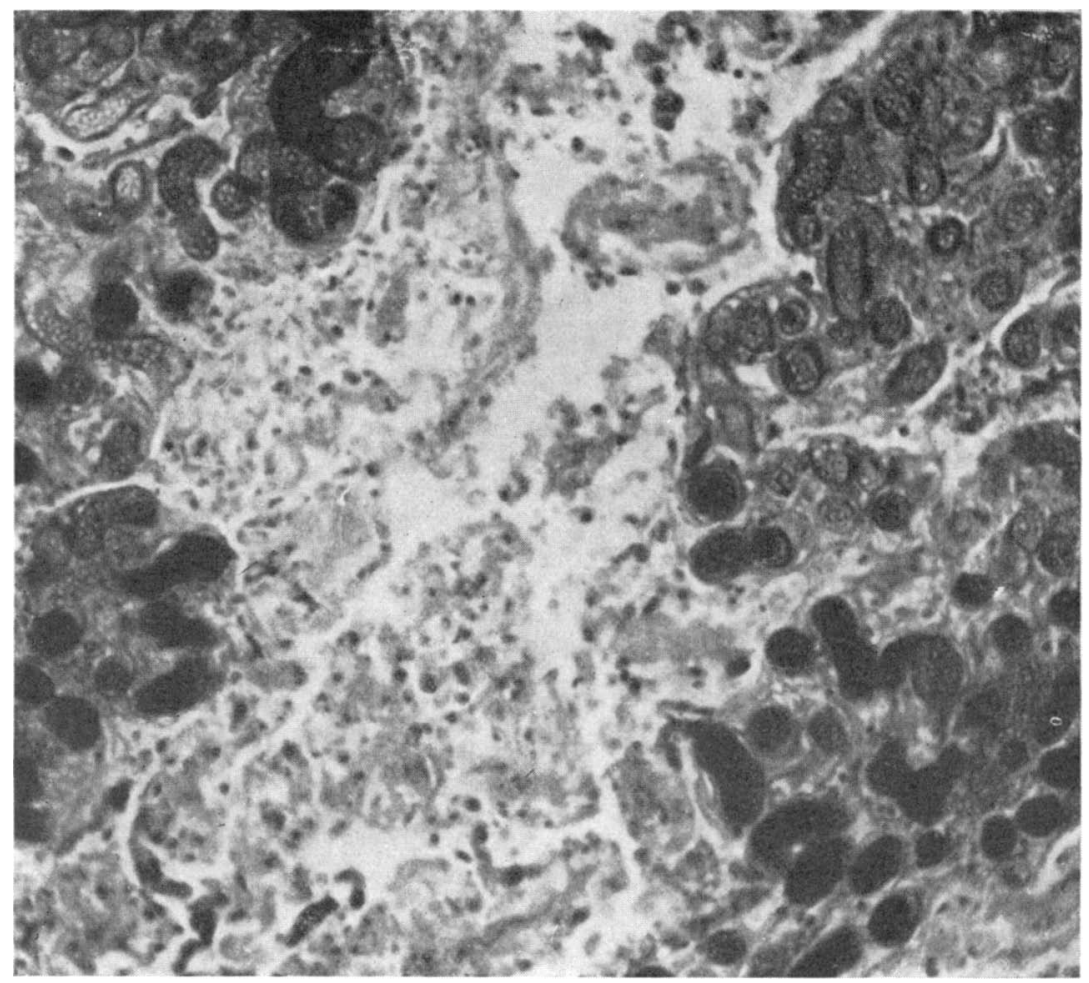

Fi g. 9. Partly macerated chorionic villus (middle) between hyperaemic cryptal walls (left and right). No cryptal epithelium is present. 2 days post partum. Firmly attached. Azan. $220 \times$.

was very tight and the capillaries were distended, especially in cases of foetal hyperaemia. As the hyperaemia was associated with proliferation of vessels, these alterations presumably began before partus. Afterbirths of this type were very firmly attached.

In a few of the placentae more or less extensive infiltrations with leucocytes were seen. The space between the allanto-chorion surrounding the placentome and the peripheral parts of the septa sometimes contained accumulations of leucocytes. In such cases bacteria could often be seen in the peripheral parts of the placentome. In placentomes of this type macerations were rare. Instead, the villi were fresh or partly necrotic. The infiltrations were only seen in placentomes taken some days after partus. 
Placentomes from "siek" cows.

The placentomes in this group did not differ much from those taken from "healthy" cows. If the afterbirth was easily removable, the picture with macerated chorionic villi was generally seen. As a matter of fact the macerations were sometimes more widespread than in the healthy cases. Thus it seems as if the afterbirths in some cases could have been expelled if the cows had been in a better condition.

The firmly attached placentomes resembled the corresponding placentomes in "healthy" cows in most respects. This is also what might be expected as the "sickness" had not necessarily anything to do with the placenta. However, in some cases the placentae from the "sick" cows presented a picture different from that in "healthy" cows. If the placentome was of the necrotic type, this kind of lesion was often more widespread and sometimes comprised all chorionic villi. Hyperaemia was more frequent in this group. In most of the placentomes leucocytes were present. They were not found immediately after partus but after one or two days. The hyperaemia and the presence of leucocytes thus indicated a placentitis caused by secondary infection post partum.

Placentomes from cows studied at the stationary clinic.

This group was heterogeneous with regard to the etiology. In the abortion cases the placentomes as a rule presented a fresh picture immediately after partus. Occasionally shrunken chorionic villi or necrotic parts were seen. Hyperaemic portions were also observed. In some of these placentomes the chorionic villi underwent autolysis, and one or two days post partum most villi were macerated. A similar course was observed in the cases of twin births. In these cases the picture at partus did not differ significantly from that of normal placentomes. Furthermore the autolysis was very rapid, the maceration being completed to a large extent within the first day post partum.

The cases of Ret. sec. where the etiology was unknown showed pictures similar to those described previously. As the placentomes were observed at partus and then at intervals during several days, the consecutive changes could be studied. Thus, at partus, the picture with extravasate blood and necrotic epithelium forming masses between the chorionic villi and cryptal walls was 


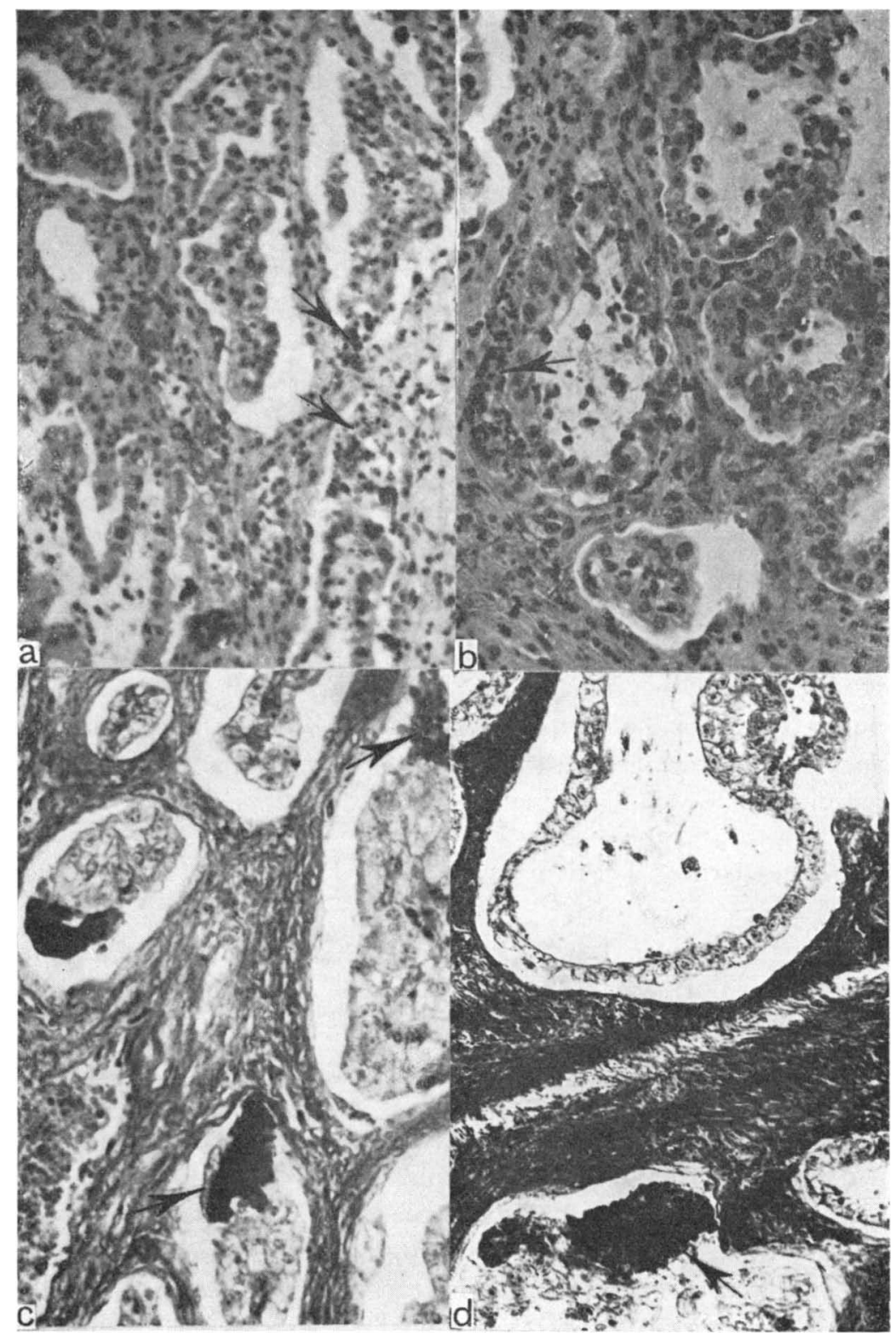

F i g. 10 . Sections from placentomes taken at intervals from one cow. The afterbirth was relatively difficult to remove. Arrows indicate necroses.

a) At partus. Most villi and crypts are intact. A few necroses are present. Hemalum + eosin. $150 \times$.

b) After 13 hours. No significant changes. Hemalum + eosin. $220 \times$.

c) After 38 hours. The villi are moderately shrunken, and some cryptal epithelium has disappeared. Azan. $220 \times$.

d) After 53 hours. The villi are still intact but most of the cryptal epithelium is lost. Azan. $220 \times$. 


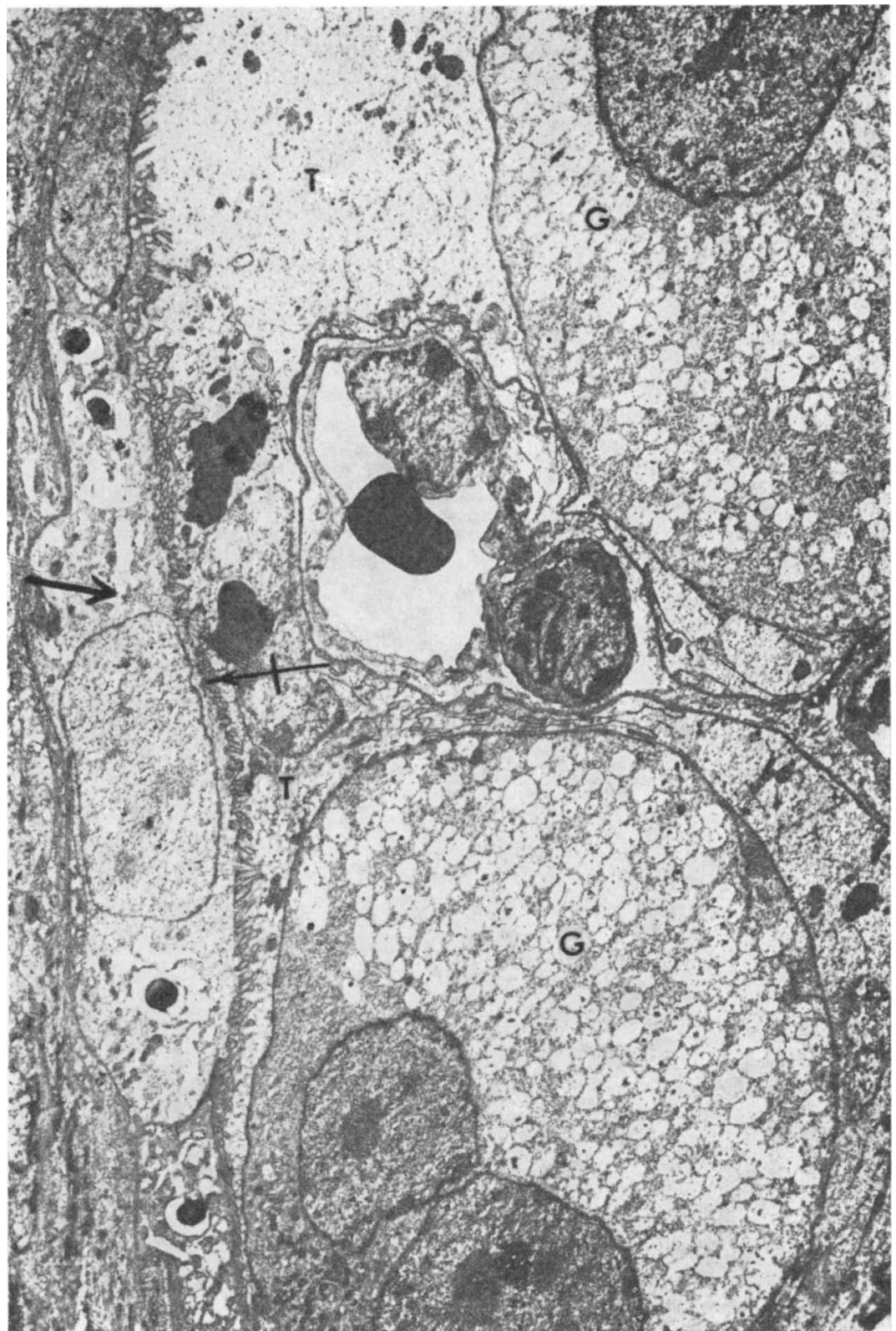

F i g. 1 1. Part of villus (right) and cryptal wall (left). The cryptal epithelium is atrophied and shows signs of degeneration $(\rightarrow$ indicates cytoplasmic vacuolisation). The line of foetal-maternal junction is intact $(+\rightarrow) . T=$ ordinary trophoblastic cell. Between two trophoblastic giant cells (G) a foetal capillary with a red cell. Electronmicrograph $4500 \times$. 


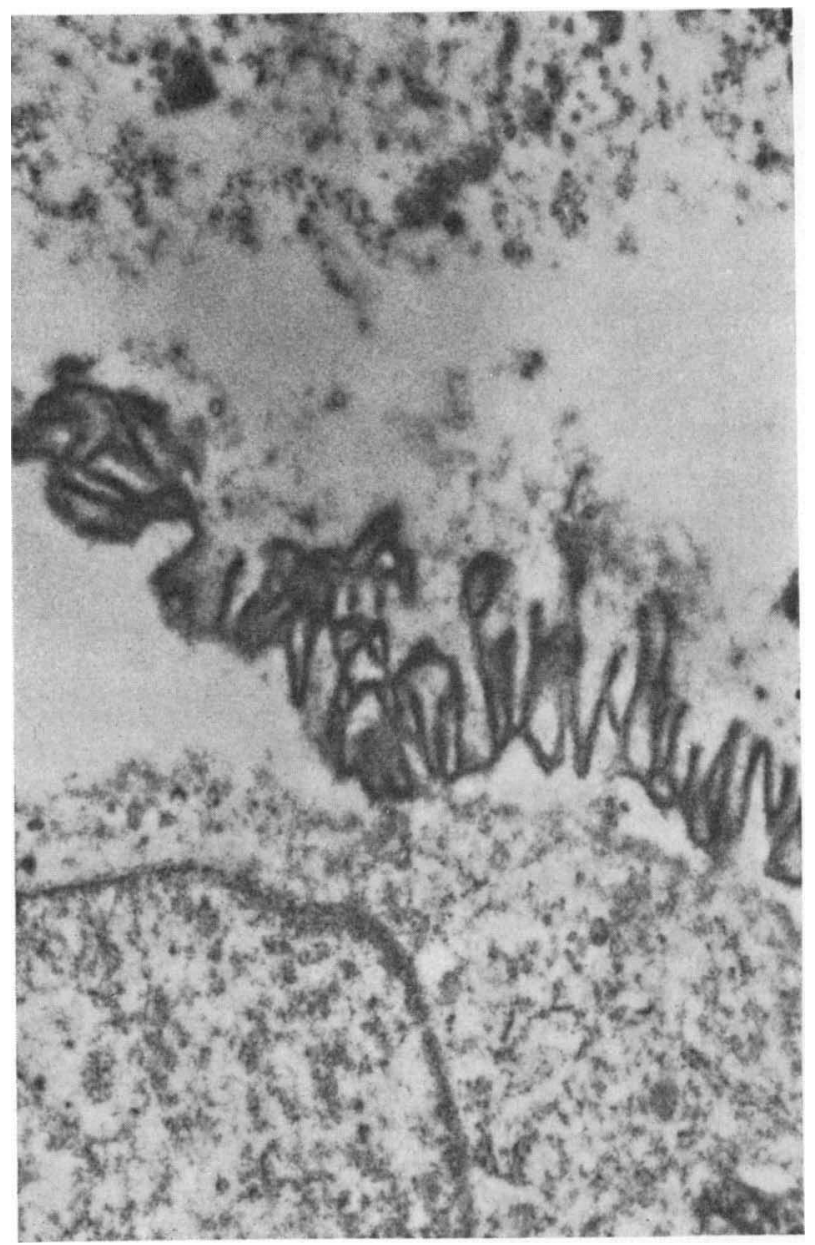

F i g. 12. Line of junction between cryptal epithelial cell (bottom) and trophoblastic cell (top). Note the defects in the cytoplasm.

Electronmicrograph $17000 \times$.

seen if the placentae were comparatively firmly attached. At partus most chorionic villi were intact with the trophoblast adhering to a vital cryptal epithelium. The mesenchymal core of the villi was large, making the villi rather thick. At some sites necroses were present. One day later the picture was unchanged, but after 2 days some alterations could be observed. The chorionic villi had shrunk to some extent. Thus the mesenchyme had undergone a slight contraction, possibly caused by a moderate dehydration. The trophoblast was as a rule intact, but at a few sites 
regressive changes had begun in the cells (vacuolization of the cytoplasm and nuclear alteration). The cryptal epithelium had been more affected. It was atrophied or desquamated. Thus the cells were very thin or the stroma was denuded. After 3 days many villi had shrunk still more. Other villi were macerated. At such sites there was a proliferation of vessels in the cryptal stroma. A series of samples taken at intervals after partus is shown in Fig. 10. The maceration phenomena were less pronounced in firmly attached placentae.

In electronmicrographs of placentomes from cows with Ret. sec. the cryptal epithelium was as a rule found to be atrophied and partly degenerated. The line of junction between trophoblast and cryptal epithelium was intact (Fig. 11), but sometimes defects in the surrounding cytoplasm occurred (Fig. 12).

One cow in this group had suffered from Ret. sec. at 3 consecutive births (Fig. 11) and could thus be regarded to have a disposition for this disease. The placentome showed the picture typical of firmly attached cotyledones with necrotic parts between the villi and cryptal walls.

\section{DISCUSSION}

A great number of factors influence the fate of the foetal membranes after partus, as has been pointed out above. When the etiology is so complex, varying appearances of the placentae might be expected. This has also been obvious in our investigation. However, the etiology was unknown in most cases, and it was not always possible to correlate the clinical status with that of the placentomes. On the other hand the placentomes could be referred to different groups, where each group had its characteristics. Especially, there were marked differences between easily removable placentae and firmly attached ones.

At normal delivery the trophoblast becomes loosened from the cryptal epithelium at the foetal-maternal line of junction (3). In the case of Ret. sec. this loosening process seems to be disturbed. In Fig. 12 the suture line is intact. Instead there are ruptures in the cytoplasm. These defects indicate that the adhesion at the suture is firmer than the strength of the cytoplasm. Thus it seems as if in retained placentae the adhesiveness between the trophoblastic and cryptal cells is maintained even after partus. In easily removable placentomes the loosening process then comes about by autolysis of the chorionic villi (Fig. 1), a process that can partly be seen in normal placentomes, too (3). The retention 
of easily removable afterbirths therefore partly seems to depend on insufficient uterine motility. A contributory cause may also be the anchoring in some crypts of fresh villi.

The major part of the placentae in our investigation were firmly attached. Except for some intermediate forms the placentomes had areas of macerated villi only to a limited extent. The firmness in attachment could sometimes be ascribed to particular causes (e. g. immature placentomes, placental hyperaemia), but in the majority of the cases no such factors were observed. These placentae had a common feature, viz. the presence of small parts of necrotic epithelium between the chorionic villi and the cryptal walls (Figs. 4 to 7 ). These necroses were present at partus and were also found in some abortion cases. Thus in this type of placentae they had presumably arisen before partus. The villi did not undergo autolysis but survived for several days after partus.

Contrary to Kennedy's (9) statement that there is no difference between placentae that become delivered normally and those which are retained we have found a significant difference between normal or easily removable placentae and firmly attached ones. Placentae of the latter kind may be regarded to represent the genuine type of Ret. sec. The disease in question should not, however, be regarded as a morbus per se. The retention is rather the main symptom of a more generalized disease. Thus Ret. sec. is also associated with other symptoms. In connection with Ret. sec. there is a highly significant delayed maturation within the neutrophil series with a very low percentage of mature neutrophils in the blood (19). A clinical observation made by many practicians is sore feet in connection with Ret. sec., which may indicate acute laminitis. This feature and the observations of blood extravasation preceding the necroses in firmly attached placentae indicate the presence of a weak haemorrhagic diathesis. This is a support for Götze's (6) conception that allergy might be one of the mechanisms involved.

The hyperaemic placentomes formed a special group among the retained afterbirths. Whether the hyperaemia was present on the foetal or maternal side the vascular proliferation indicated that the alterations had begun before partus. These placentae were always very firmly attached. The hyperaemic picture gave one the impression that the conception $(6,12,13,16)$ that the blood pressure is essential for maintaining the foetal-maternal connection may have some relevance. As the blood is retained in 
this type of placentomes, the villi may remain incarcerated in the crypts. These placentae, however, represented only a minor part of the cases.

The placentomes in which leucocytes and/or bacteria were found had always been attached for some days. In the cases where it was possible to sample placentomes immediately after partus bacteria were never found in them. If infections had been manifest before partus, which had possibly been the case in the hyperaemic placentomes, this etiological factor has played a subordinate rôle in our material. Our observations support Kugeler's (10) conception that placentitis is a secondary phenomenon. Secondary placentitis does not cause maceration of the villi. Thus there is no morphological evidence to support the view that bacteria contribute to faciliate the delivery.

The state of health of the cows could not be significantly correlated to the morphology of the placentomes. One could only observe that easily removable placentae seemed to be retained because the cows were too weak to expel them, and that the occurrence of hyperaemia and/or leucocytic infiltrations (placentitis) was more frequent in "sick" cows.

To sum up, we have found that in firmly attached placentae 3 main types can be distinguished each of which has its dominant feature.

1. Placentomes which are fresh for several days. They are not "ready" for delivery (abortion).

2. Placentomes with necrotic portions between the chorionic villi and the cryptal walls. This type is the dominating one.

3. Placentomes with hyperaemia.

The technical assistance of Miss Carin Gerdin is gratefully acknowledged.

\section{REFERENCES}

1. Björkman, N.: Acta anat. 1954, suppl. $22=2$ ad vol. 22. Morphological and Histochemical Studies on the Bovine Placenta (Diss.).

2. Björkman, N. and Bloom, G.: Z. Zellforsch. 1957, 45, 649.

3. *) Björkman, N. and Sollén, P.: Acta vet. scand. 1960, 1, 347.

4. Boyd, W. L. and Sellers, A. F.: Cornell Vet. 1948, 38, 263.

5. Fincher, M. G.: J. Amer. vet. med. Ass. 99, 395.

6. Götze, R.: Dtsch. tierärztl. Wschr. 1941, 49, 598.

*) In our publication Acta vet. scand. 1960, 1, 347 the magnification of Fig. 2 is $2000 \times$ not $200 \times$. Figs. 5, 7, 9, 10, 11 and 12 are reduced about $50 \%$, the legends indicate the original magnifications. 
7. Hallman, E. T.: Cornell Vet. 1924, 14, 254.

8. Hart, G. H., Mead, W. S. and Guilbert, H. R.: Proc. Soc. exp. Biol., N.Y. 1933, 30, 1230.

9. Kennedy, A. J.: Vet. Rec. 1947, 59, 519.

10. Kugeler, E.: 1932, Untersuchungen an Placentome vom Rinde bei normalem und verzögertem Abgang der Nachgeburt, Hannover (Diss.).

11. Mc Donald, L. E., Mc Nutt, S. H. and Nichols, R. E.: Amer. J. vet. Res., 1954, 15, 22.

12. Pomayer, C.: Das Zurückhalten der Nachgeburt beim Rind, 1919, 2, Berlin (Diss.).

13. Rienmann, A. Th.: Medlemsbl. danske Dyrlægeforen. 1954, 37, 445.

14. Ronning, M., Berousek, C. R., Kuhlman, A. H. and Gallup, W. D.: J. Dairy Sci. 1953, 36, 52.

15. Schmid, G.: Schweiz. Arch. Tierheilk. 1927, 69, 530.

16. Stewart, S. L.: Vet. Med. 1939, 34, 94.

17. Tarver, W. J.: Brit. vet. J. 1952, 108, 256.

18. Williams, W. L., Udall, D. H., Frost, J. N., Goldberg, S. A., Cushing, E. R., Fincher, M. G., and Mabey, M. H.: Cornell Vet. 1924, $14,315$.

19. Winqvist, G.: Acta vet. scand. 1959, 1, 27.

\section{SUMMARY}

A morphological investigation of retained afterbirth in cows has been undertaken on 93 spontaneous cases. If the afterbirth was easily removable, the placentome showed almost the same picture as normal placentomes at partus with intact trophoblast and cryptal epithelium. Then autolysis of the chorionic villi appeared, beginning in the trophoblast. The firmly attached placentae were mainly of 3 types:

1. The placentomes generally showed a normal picture at partus. No autolysis occurred during the first days, and the chorionic villi survived. The placenta was not "ready" for delivery. This type mostly appeared at abortions.

2. The placentomes showed very characteristic necroses, preceded by small bleedings. Otherwise they showed fresh tissue which remained intact for several days, and also macerated villi. Most of the placentae were of this type and the presence of necroses seems to be characteristic of the genuine form of firmly attached placentae.

3. Placentomes with hyperaemia (placentitis).

The investigation indicates that the normal separation between the microvilli of the cryptal epithelium and the trophoblast does not occur at Ret. sec., probably owing to maintained adhesiveness, and also that the chorionic villi survive.

\section{ZUSAMMENFASSUNG}

Eine morphologische Untersuchung der zurückgebliebenen Nachgeburt bei Rindern.

Eine morphologische Untersuchung der zurückgebliebenen Nachgeburt bei Rindern wurde in 93 spontanen Fällen unternommen. Wenn 
die Nachgeburt sich leicht entfernen liess, wies das Plazentom im grossen und ganzen das selbe Bild auf wie das normale Plazentom bei Partus mit intaktem Trophoblast und Kryptepithel. Später trat Autolysis in der Chorionvilli ein mit Anfang im Trophoblast. Die fest sitzenden Nachgeburten waren hauptsächlich von drei Arten, und zwar

1. Das Plazentom wies bei Partus ein im grossen und ganzen normales Bild auf, aber Autolysis setzte während der ersten Tage nicht ein, sondern die Chorionvilli überlebten. Die Plazenta war für Ablösung nicht „reif“. Dieser Typus kam haputsächlich bei Abortus vor.

2. Das Plazentom zeigte sehr characteristische Veränderungen in Form von Nekrosen, denen kleine Blutungen vorangingen. Im übrigen kam gesundes Gewebe vor, das sich mehrere Tage intakt hielt, ebenso wie mazerierte Villi. Die meisten Nachgeburten waren von solcher Art, und das Vorhandensein von Nekrosen schien für die echte Form von fest sitzenden Nachgeburten kennzeichnend zu sein.

3. Plazentom mit Hyperaemia (Plazentitis).

Die Untersuchung ergibt, dass die natürliche Ablösung bei Ret. sec. zwischen den Mikrovilli des Kryptepithels und denen des Trophoblasts ausbleibt, wahrscheinlich infolge der erhaltenen Adhesivität, und dass die Chorionvilli weiterleben.

\section{SAMMANFATTNING}

En morfologisk undersökning av kvarbliven efterbörd hos nötkreatur.

En morfologisk undersökning av kvarbliven efterbörd hos nötkreatur har företagits på 93 spontana fall. Om efterbörden var lätt avlossbar, visade placentomen i stort sett samma bild som normala placentom vid partus med intakt trophoblast och kryptepitel. Sedermera inträdde en autolys i chorionvilli med början i trophoblastet. De hårt sittande efterbördarna voro av huvudsakligen 3 slag:

1. Placentomen visade vid partus en i stort sett normal bild, men någon autolys satte ej in under de första dagarna, utan chorionvilli överlevde. Placentan var ej „mogen“ för avlösning. Denna typ förekom huvudsakligen vid aborter.

2. Placentomen visade mycket karakteristiska förändringar i form av nekroser föregångna av små blödningar. För övrigt förekom frisk vävnad, som höll sig intakt i flera dagar, samt macererade villi. De flesta efterbördarna voro av detta slag och närvaron av nekroser synes vara ett karakteristikum för den genuina formen av hårt sittande efterbördar.

3. Placentom med hyperaemi (placentit).

Undersökningen ger vid handen att vid Ret. sec. den naturliga avlösningen mellan kryptepitelets och trophoblastets mikrovilli uteblir, sannolikt till följd av bibehållen adhesivitet, samt att chorionvilli lever vidare. 